in younger patients, though it must be recognized that frequently this may require a bilateral block dissection, since many of these tumours metastasize to both sides of the neck. One of the common causes of death is recurrence in the cervical region, and E. W. Strong and colleagues ${ }^{11}$ have shown that the rate can be reduced by giving low doses of irradiation before operation. In a controlled trial they found reduction of cervical recurrence rates from $50 \%$ to $31 \%$ when this was done.

1 Pichler, A. G., Williams, J. R., and Moore, J. A., Archives of Otolaryngo$\log y, 1972,95,178$.

2 Venables, C. W., and Craft, I. L., British fournal of Cancer, 1967, 21, 645

${ }^{3}$ Shedd, D. P., Von Essen, C. F., Ferraro, R. H., Connelly, R. R., and Eisenberg, H., Cancer, 1968, 21, 89.

4 Payne, P. M., and Dixon, R. A., South Metropolitan Cancer Registry Bulletin, 1966, No. 4

5 Saxena, V. S., Cancer, 1970, 26, 788.

- Smith, N., Australian Dental fournal, 1968, 13, 333.

7 Wawro, N. W., Babcock, A., and Ellison, L., American fournal of Surgery, $1970,119,455$.

${ }^{8}$ Feind, C. R., and Cole, R. M., American fournal of Surgery, 1968, 116, 482 - Flamant, R., Hayem, M., Lazar, P., and Denoix, P., Cancer, 1964, 17, 377.

10 Sutton, P. R. N., Medical fournal of Australia, 1968, 2, 312.

11 Strong, E. W., et al., Cancer, 1966, 19, 1509.

\section{Gastritis and Gastric Cancer}

About 15,000 people die every year in the United Kingdom from gastric cancer, ${ }^{1}$ but little is known about the causes of the disease. Though it shows a familial incidence, genetic inheritance cannot account for more than a small proportion of that, and while dietary factors are probably of considerable and perhaps paramount importance in causing it epidemiological studies designed to identify them have proved unhelpful. But they have drawn attention to the possibility of causes in the environment by disclosing geographical fluctuations of almost ten-fold between areas of high and low incidence. ${ }^{2}$ Moreover, the risks of contracting the disease vary in migrants to areas with different incidence rates. ${ }^{3}$

The best-known premalignant condition of the stomach is pernicious anaemia. ${ }^{45}$ The risk of gastric cancer is probably four to five times higher in such patients than in the general population. ${ }^{6}$ It has been suggested that this association arises by two pathways, one associated with the increased frequency of blood group $\mathrm{A}$ in patients with either disease, and the other independent, ${ }^{7}$ but it now seems probable that the association is entirely independent of the blood groups. ${ }^{8}$ One possibility is that autoimmune atrophic gastritis is a premalignant condition. But only a minor proportion of patients with gastric cancer prove to have circulating gastric antibodies, ${ }^{9}$ and it would therefore be of considerable interest to know whether the presence of simple chronic superficial or atrophic gastritis increases the risk of later development of gastric cancer.

M. Siurala and his colleagues ${ }^{10}$ found nine gastric cancers in 116 patients with atrophic gastritis diagnosed by gastric biopsy some 10-15 years earlier, and in a recent survey I. R. Walker and his associates ${ }^{11}$ found four gastric cancers in 40 patients found to have "simple" atrophic gastritis from 10 to 22 years earlier. Though exact mathematical comparisons are impossible, these figures are at least equivalent to the risks associated with pernicious anaemia. When the likely frequency of atrophic gastritis in the population is taken into account-as much as $28 \%$ if figures obtained in a normal Finnish population are generally applicable ${ }^{12}$-then atrophic gastritis becomes of greater importance in absolute terms.

Predisposing factors to atrophic gastritis are poorly understood, but a variety of constitutional factors have been suggested, including tobacco smoking and alcohol consumption as well as (weakly) social class. ${ }^{13}$ But there is a far stronger relationship between social class and gastric cancer mortality, with a notably high death rate in the lowest social classes, ${ }^{14}$ a risk which may be increasing rather than diminishing, ${ }^{14} 15$ though changing bases of occupational classification make comparisons difficult. Further investigations of the significance of atrophic gastritis and intestinal metaplasia-also sometimes considered to be a precursor of gastric cancer ${ }^{16}{ }^{17}$ are clearly needed. But it has to be borne in mind that gastric biopsy, a technique which may be simple and trouble-free in experienced hands, is still physically unpleasant for the patient undergoing it.

1 Mortality from Malignant Neoplasms, 1955-65, Part 2. Geneva, World Health Organization, 1970.

Doll, R., Payne, P., and Waterhouse, J. A. H., Cancer Incidence in Five Continents, Vol. i. Berlin, Springer Verlag, 1966.

3 Buell, P., and Dunn, J. E., Cancer (Philadelphia), 1965, 18, 656.

4 Magnus, H. A., Fournal of Clinical Pathology, 1958, 11, 289.

5 Mosbech, J., and Videbaek, A., British Medical fournal, 1950, 2, 390.

6 Blackburn, E. K. et al. International fournal of Cancer, 1968, 3, 163.

7 Hoskins, L. C., Loux, H. A., Britten, A., and Zamcheck, N., New England

Fournal of Medicine, 1965, 273, 633 .
8 Callender, S., Langman, M. J. S., MacLeod, I. N., Mosbech, J., and Rahtkens Nielsen, K., Gut., 197i, 12, 465.

9 Kravetz, R. E.. Van Noorden, S., and Spiro, H. M., Lancet, 1967, 1, 235

10 Siurala, M., Varis, K., and Wiljasalo, M., Scandinavian fournal of Gastroenterology, 1966, 1, 40.

1 Walker, I. R., Strickland, R. G., Ungar, B., and Mackay, I. R., Gut, 1971, 12, 906.

2 Siurala, M., Isokoski, M., Varis, K., and Kekki, M., Scandinavian Fournal of Gastroenterology, 1968, 3, 211 .

${ }^{3}$ Edwards, F. C., and Coghill, N. F., British Medical fournal, 1966, 2, 1409.

14 Registrar General's Decennial Supplement, England and Wales, Occupational Mortality, 1951, part 1. London, H.M.S.O., 1954.

15 Registrar General's Decennial Supplement, England and Wales, Occupational Mortality Tables, 1961. London, H.M.S.O., 1971.

${ }^{16}$ Morson, B. C., British fournal of Cancer, 1955, 9, 377.

17 Siurala, M., Eramaa, E., and Tapiovaara, J., Acta Medica Scandinavica 1959, 164, 431 .

\section{Traumatic Displacement of Fat}

Most of the disabilities and deformities that follow injury are becoming known and well documented, but with the inexorable increase in road traffic accidents and with increasing efficiency in accident services new syndromes are being recognized and reported. Trauma to the hip region in women may cause a rupture of fat tissue with displacement, leaving an ugly lump with an adjacent defect. This condition had not been reported until B. F. Meggitt and J. N. Wilson" described the "battered buttock syndrome," "fat fracture," or "traumatic lipoma" in 12 women, nearly all of whom were injured in car accidents.

The clinical features are not obvious at first because the swelling is large and is mainly due to haematoma. As the bruising becomes absorbed the deformity becomes apparent. There is a large tender mass the size of which is accentuated by the adjacent hollow. Three of the 12 cases reported required operation because the deformity was accompanied by pain and tenderness. At operation the subcutaneous fat was found to have been sheared off the deep fascia, the vertical fibrous septa having been ruptured. In one case an attempt to replace the fat mass was partially successful. In 